\title{
Hubungan Antara Kepercayaan Diri Dengan Kecemasan Bertanding Anggota Komunitas Tari Modern Di Kota Padang
}

\author{
Ajeng Wulandari, Harry Theozard Fikri, Krisnova Natasia \\ Fakultas Psikologi, Universitas Putra Indonesia "YPTK" Padang, Indonesia \\ email: ajengwulandari702@gmail.com harrytheozard@yahoo.com krisnova88@gmail.com
}

\begin{abstract}
The aim of this study is to assess the relationship between self-confidence and competing anxiety A member of the Padang City Modern Dance Community. In this study the independent variables are self-confidence, and the dependent variable is anxiety for competition. The measuring instrument used in this study is a level of selfconfidence and a competing scale of anxiety.In this study the sampling technique uses the technique of nonprobability sampling. 105 members of the modern dance community in Padang city were the sample in this study. Alpha Cronbach technique was used in validity and reliability tests in this study. The validity of coefficient results on the confidence scale moves from $r x-0.341$ to $r-0.889$ with a reliability coefficient of a-0.943, while the competition anxiety scale moves from rix0.324 to $r-0.737$ with a reliability coefficient of $a=0.919$. The correlation value was -0.571, with a meaning level of 0.000, which means the hypothesis is accepted, based on the data analysis.This indicates a relationship significant among the members of the modern dance community in Kota Padang between self-confidence and competing anxiety.
\end{abstract}

Keywords: self-confidence, competitive anxiety, dance community.

\begin{abstract}
Abstrak
Penelitian ini bertujuan untuk mengetahui hubungan antara kepercayaan diri dengan kecemasan bertanding pada anggota komunitas tari modern Kota Padang. Variabel bebas dalam penelitian ini adalah kepercayaan diri dan variabel terikat adalah kecemasan bertanding. Alat ukur yang digunakan dalam penelitian ini adalah skala kepercayaan diri dan skala kecemasan bertanding. Teknik pengambilan sampel dalam penelitian ini menggunakan teknik non-probability sampling. Sampel dalam penelitian ini adalah 105 orang anggota komunitas tari modern di kota padang. Uji validitas dan reliabilitas pada penelitian ini menggunakan teknik Alpha Cronbach. Hasil koefisien validitas pada skala kepercayaan diri bergerak dari $\mathrm{r}_{\mathrm{ix}}=0,341$ sampai dengan $\mathrm{r}_{\mathrm{ix}}=0,889$ dengan koefisien reliabilitas sebesar $\alpha=0,943$ sedangkan pada skala kecemasan bertanding bergerak dari $r_{i x}=0,324$ sampai dengan $r_{i x}=0,737$ dengan koefisien reliabilitas sebesar $\alpha=0,919$. Berdasarkan analisis data, diperoleh nilai korelasi sebesar -0,571 dengan taraf signifikansi 0,000 yang berarti hipotesis diterima. Hal ini menunjukkan bahwa ada hubungan yang signifikan antara kepercayaan diri dengan kecemasan bertanding pada anggota komunitas tari modern di Kota Padang.
\end{abstract}

Kata Kunci: kepercayaan diri, kecemasan bertanding, komunitas tari.

\section{Pendahuluan}

Manusia menurut Kamus Besar Bahasa Indonesia (KBBI) adalah makhluk yang berakal budi atau mampu menguasai makhluk lain. Secara bahasa manusia berasal dari kata "manu" (Sansekerta), "mens" (Latin), yang berarti berpikir, atau makhluk yang berakal budi. Secara istilah manusia dapat diartikan sebuah konsep atau sebuah fakta, sebuah gagasan atau realitas, sebuah kelompok (genus) atau seorang individu. Manusia sebagai makhluk sosial saling membutuhkan antara satu individu dengan individu lainnya. Baik itu dalam rangka kegiatan sosial, ekonomi, maupun politik. Sebagai makhluk sosial tentu saja manusia pasti berinteraksi antara satu dengan yang lain, demi terjalinnya interaksi yang teratur dan harmonis maka dibutuhkan sebuah aturan. Menurut Paula J. C. \& Janet W. K. Manusia merupakan makhluk yang terbuka, bebas memilih makna di dalam setiap situasi, mengembang tanggung jawab atas setiap keputusan, yang hidup secara berkelanjutan, 
serta turut menyusun pola hubungan antar sesama dan unggul multidimensional dengan berbagai kemungkinan. Manusia sebagai makhluk Tuhan yang paling sempurna menciptakan kebudayaan mereka sendiri dan melestarikannya secara turun menurun. Budaya tercipta dari kegiatan sehari hari dan juga dari kejadian - kejadian yang sudah diatur oleh Yang Maha Kuasa.

Kebudayaan berasal dari kata budaya yang berarti hal-hal yang berkaitan dengan budi dan akal manusia. Menurut Andreas Eppink, kebudayaan mengandung keseluruhan pengertian nilai sosial,norma sosial, ilmu pengetahuan serta keseluruhan struktur-struktur sosial, religius, dan lain-lain, tambahan lagi segala pernyataan intelektual dan artistik yang menjadi ciri khas suatu masyarakat. Definisi Kebudyaan itu sendiri adalah sesuatu yang akan mempengaruhi tingkat pengetahuan dan meliputi sistem ide atau gagasan yang terdapat dalam pikiran manusia, sehingga dalam kehidupan sehari-hari, kebudayaan itu bersifat abstrak. Namun kebudayaan juga dapat kita nikmati dengan panca indera kita. Lagu, tari, dan bahasa merupakan salah satu bentuk kesenian dari kebudayaan yang dapat kita rasakan.Kesenian adalah salah satu isi dari kebudayaan manusia secara umum, karena dengan berkesenian merupakan cerminan dari suatu bentuk peradaban yang tumbuh dan berkembang sesuai dengan keinginan dan cita - cita yang berpedoman kepada nilai - nilai yang berlaku dan dilakukan dalam bentuk aktifitas berkesenian, sehingga masyarakat mengetahui bentuk keseniannya. Kesenian sebagai karya atau hasil simbolisasi manusia merupakan sesuatu yang misterius. Namun demikian, secara universal jika berbicara masalah kesenian, orang akan langsung terimajinasi dengan istilah "indah.

Kesenian adalah bagian dari budaya dan merupakan sarana yang digunakan untuk mengekspresikan rasa keindahan dari dalam jiwa manusia. Tidak hanya itu saja, kesenian dapat digunakan untuk melanggengkan norma dan adat istiadat suatu masyarakat agar tidak lekang dimakan jaman. Kesenian tidak pernah lepas dari masyarakat. Sebagai salah satu bagian yang penting dari kebudayaan, kesenian adalah ungkapan kreatifitas dari kebudayaan itu sendiri. Masyarakat yang menyangga kebudayaan dan juga kesenian, mencipta, memberi peluang untuk bergerak, memelihara, menularkan, mengembangkan untuk kemudian menciptakan kebudayaan baru lagi. Selain itu kesenian juga merupakan sarana untuk pertandingan. Pertandingan atau yang bisa disebut juga dengan kompetisi adalah kegiatan olahraga untuk meningkatkan kemampuan prestasinya dalam bentuk kegiatan fisik yang saling berhadaphadapan. Kompetisi sebagai sebuah proses sosial yang terjadi ketika penghargaan diberikan kepada orang - orang atas dasar tentang bagaimana penampilan seseorang dibandingkan dengan kinerja orang lain melakukan tugas yang sama atau berpatisipasi pada acara yang sama dan penghargaan dalam kompetisi terbatas kepada orang yang menggunguli orang lain. Selain itu kompetisi kesenian memiliki berbagai macam bentuk dan media. Kesenian dapat dinikmati melalui media pendengaran (audio art), penglihatan (visual art), dan kombinasi keduanya (audio visual art). Secara umum, seni dapat dibedakan menjadi lima kelompok, yaitu: Seni Musik, Seni Rupa, Seni Sastra, Seni Teater, Seni teater dan Seni Tari . Pembagian dari kesenian itu sendiri yang sangat beragam, salah satunya adalah seni tari yang memanfaatkan gerakan tubuh sebagai keindahan. Seorang pengarah tari (koreografer) dapat menyampaikan maksud atau pesan tertentu melalui gerakan tarian, seni tari ini juga terdapat dua bagian, yaitu tari tradisional ( etnic ) tari modern (dance ). Tari tradisional adalah tarian yang diciptakan untuk menyambut acara - acara adat tertentu dan memakai pakaian sesuai dengan pakaian adat setempat. sedangkan tari modern atau tari masa kini adalah bentuk tarian yang merupakan ciptaan kaum muda yang diikuti oleh alunan music dan didominasi oleh emosi atau rasa sebagaimana ciri kondrati emosi manusia yang memiliki desakan untuk ingin bebas, maka jenis tari ini lebih mengarah untuk bebas dari tradisi . tarian modern sudah tidak asing lagi dimata masyarakat, banyak masyarakat khususnya kaum remaja yang berkreasi dan memiliki kreatifitas yang tinggi dibidang tari modern , kaum remaja tersebut bebas disini adalah bebas untuk berkreasi membuat gerakan yang tidak diharuskan oleh pola - pola yang sudah ada dan buat sebagus mungkin dan sekereatif mungkin. Fungsi seni secara umum adalah sebagai bentuk/ cara penyampaian ekspresi seseorang kepada orang lain dan lingkungannya. Orang - orang bisa merasa terhibur ketika melihat sebuah lukisan, menonton bioskop, atau menonton sebuah konser music atau seni tari yang diadakan di tempat umum dan kemudian dijadikan suatu perlombaan atau dijadikan tempat berkompetisi seperti yang sudah banyak diadakan diberbagai tempat di Indonesia .

Kompetisi sebagai suatu proses yang dimana proses kompetitif yang dialami setiap individu berbeda. situasi-situasi kompetitif, yang merupakan suatu proses yang menentukan apakan respons kecemasan sebelum kompetisi akan terjadi atau tidak. Apabila situasi kompetisi menghasilkan kekhawatiran, 
perasaan gelisah dan meningkatnya aktivitas fisiologis maka akan diikuti dengan respons kecemasan (anxiety). Anxiety adalah suatu gejala psikologis yang identik dengan perasaan negatif. Anxiety dapat timbul kapan saja, dan salah satu penyebab terjadinya anxiey adalah ketegangan yang berlebihan yang berlangsung lama. Menurut Hawari (2001) kecemasan adalah gangguan alam perasaan (affective) yang ditandai dengan perasaan ketakutan atau kekhawatiran yang mendalam dan berkelanjutan, tidak mengalami gangguan dalam menilai realitas, kepribadian masih tetap utuh ( tidak mengalami keretakan kepribadian/splitting of personality), perilaku dapat terganggu, tetapi masih dalam batasbatas normal. Perasaan negative atau cemas diakibatkan karena bayangan sebelum pertandingan dan saat pertandingan dapat disebut juga sebagai kecemasan bertanding.

Kecemasan bertanding (Competitive anxiety) merupakan suatu hal negatif dalam hal menghadapi kompetisi karena dapat menurunkan capaian prestasi. Menurut Jamshidi (2011) Kecemasan bertanding (competitive anxiety) merupakan salah satu tipe kecemasan yang dalam beberapa tahun terakhir telah dipertimbangkan di bidang psikologi khususnya psikologi olahraga yang beberapa tahun terakhir sedang mengalami perkembangan, di mana competitive anxiety didefinisikan sebagai suatu keiginan untuk memahami setiap pertandingan, serta salah satu faktor yang mengancam terhadap situasi perasaan khawatir dan tertekan. Menurut Miftah (2017) Kecemasan bertanding ini biasanya akan mengganggu penampilan penari karena muncul perasaan takut untu gagal atau menimbulkan beban moral jika tidak bisa menang . Competitive anxiety ( kecemasan bertanding) terjadi karena adalah tekanan - tekanan kejiwaan ketika bermain dan sifat kompetisi yang didalamnya penuh dengan perubahan dari keadaan permainan atau kondisi alam yang membuat menurunnya kepercayaan diri dari penampilan.

Self confidance (percaya diri) merupakan aspek kepribadian yang mutlak harus dimiliki olah seorang yang ikut dalam bertanding karena berkaitan dengan keyakinan "saya bisa". Meskipun sering mendengar penari dan pelatih berbicara tentang percaya diri diatas panggung . itu bukan istilah yang mudah untuk dapat dipraktekkan. Kepercayaan diri atau self confident adalah kepercayaan akan kemampuan terbaik diri sendiri yang memadai dan menyadari kemampuan yang dimiliki, dapat memanfaatkannya secara tepat untuk menyelesaikan serta menanggulangi suatu masalah dengan situasi terbaik dan dapat memberikansesuatu yang menyenangkan bagi orang lain. Menurut Horn (2008) self confidance sebagai keyakinan bahwa seseorang memiliki sumber daya internal , terutama kemampuan, untuk mencapai keberhasilan . self confidance akan menimbulkan rasa aman yang dapat dilihat dari sikap dan tingkah laku yang tampak tenang, tidak mudah ragu - ragu dan, tidak mudah gugup dan tegas. self confidance adalah rasa percaya pada kemampuan sendiri untuk mampu mencapai prestasi tertentu dan apabila prestasinya sudah tinggi maka individu tersebut akan lebih self confidance. Menurut Setyobroto ( 2002 ) Self confidance atau kepercayaan diri merupakan modal utama seorang atlet untuk maju karena pencapaian prestasi yang tinggi harus dimulai dengan percaya bahwa kemampuan dan sanggup melampaui prestasi yang diraih.

Berdasarkan hasil wawancara awal yang dilakukan kepada Pelatih pada komunitas tari modern di Kota Padang, bahwa anggota (dancer) tersebut ada yang memiliki kecemasan yang saat bertanding. Hal ini dibuktikan karena anggota tersebut mengatakan kepada pelatih bahwasanya anggota tersebut merasa nervous saat akan bertanding. Hal ini dikuatkan juga oleh anggota yang mengatakan bahwa kecemasan yang mereka miliki saat pertandingan dan tidak ada keyakinan membuat ketidaknyamanan dalam diri mereka sendiri, seperti perut sakit sebelum memulai pertandingan, dan juga anggota tubuh tertentu mempunyai respon yang berbeda seperti jari tangan yang mendadak dingin, detak jantung semakin cepat, berkeringat dingin, dan ada juga yang mengalami kepala pusing pada saat pertandingan. Hal ini terjadi karena mereka merasa tidak mampu ketika bertemu dengan rivalnya dalam suatu pertandingan . meskipun beberapa di antara mereka sudah sangat sering bertemu dan bertatap muka pada saat pertandingan, namun tetap memiliki kecemasan, hal tersebut timbul akibat rasa akan ketidakmampuan untuk mencapai kemenangan dalam suatu perlombaan Perlombaan yang sering diadakan dan difasilitasi di beberapa tempat di Kota padang membuat anggota dari masing - masing komunitas sering bertemu dalam suatu pertandingan dan menganggap bahwa persaingan semakin ketat untuk mencapai kemenangan karna diantara mereka saling ingin menjadi juara dan semakin kiat dalam berlatih, akibatnya kecemasan yang berlebihan tersebut terjadi pada anggota mulai dari awal berlangsungnya pertandingan, hingga pertandingan selesai. . 


\subsection{Kecemasan Bertanding}

Menurut Smith, Smoll, Cumming, dan Grossbard, (2006) kecemasan bertanding adalah keadaan bagian otak yang berbeda yang terlibat dalam berbagai aspek kecemasan bertanding, khususnya perbedaan kongnitif dan somatik, meski mereka berinteraksi satu sama lain, kecemasan kongnitif dan somatik dapat sewaktu -waktu terjadi. Kecemasan bertanding (competitive anxiety) merupakan salah satu tipe kecemasan yang dalam beberapa tahun terakhir telah dipertimbangkan di bidang psikologi khususnya psikologi olahraga yang beberapa tahun terakhir sedang mengalami perkembangan, di mana competitive anxiety didefinisikan sebagai suatu keiginan untuk memahami setiap pertandingan, serta salah satu faktor yang mengancam terhadap situasi perasaan khawatir dan tertekan (Jamshidi et al., 2011).Competitive anxiety ( kecemasan bertanding) merupakan suatu hal negatif dalam hal menghadapi kompetisi karena dapat menurunkan capaian prestasi.

Competitive anxiety adalah salah satu tipe kecemasan yang beberapa tahun terakhir telah dipertimbangkan dibidang psikologi khususnya psikologi olahraga. Menurut Miftah (2017) Kecemasan bertanding ini biasanya akan mengganggu penampilan penari karena muncul perasaan takut untu gagal atau menimbulkan beban moral jika tidak bisa menang .Menurut Gunarsa (2008) kecemasan bertanding merupakan salah satu faktor psikologis yang dapat memengaruhi seorang atlet dalam situasi pertandingan. Hal ini tidak dapat dihindari dan dipastikan ada dalam situasi pertandingan, sehingga menjadi salah satu penyebab kegagalan atau performa yang tidak maksimal oleh atlet. Ia juga mengatakan kecemasan akan semakin meningkat bila semakin mendekati waktu bertanding, hal ini dikarenakan adanya bayangan akan beratnya pertandingan yang akan dihadapi. Mellalieu, Hanton, dan Fletcher (2009) mengatakan bahwa kecemasan bertanding merupakan respon emosional negatif spesifik terhadap stres dalam bertanding. Hal ini berarti kondisi emosional negatif yang dirasakan atlet akan turut memengaruhi tingkat kecemasan yang dirasakan atlet saat akan bertanding.Adanya kecemasan dapat muncul karena adanya pemikiran dan kegelisahan akan diri atlet karena merasa belum cukup siap untuk bertanding, atau atlet pernah merasakan kekalahan pada sebelumnya yang mendorongnya untuk ragu akan kemampuan yang ia punya.Berdasarkan pengertian diatas dapat disimpulkan bahwa kecemasan bertanding merupakan kondisi dimana seseorang memiliki kondisi emosional negative atau kegelisahan dari diri sendiri dan merasa tidak mampu mencapai kemenangan saat bertanding.

\subsection{Aspek - Aspek Kecemasan Bertanding}

Smith, Smoll, Cumming, dan Grossbard, (2006), membuat pengukuran dengan membagi kecemasan kompetitif menjadi 3 dimensi, yaitu: Somatic, Worry, dan Concentration disruption. Aspek Worry, dan Concentration disruption merupakan aspek yang bersumber pada kecemasan kognitif.

(1) Somatic, Smith, Smoll, Cumming, dan Grossbard, (2006), mengindikasikan somatic dengan berbagai indeks autonomic arousal yang berpusat di perut dan otot. Somatic anxiety (kecemasan somatis) mengacu kepada perubahan fisiologi pada atlet. Gejala negatif seperti perasaan gugup, tekanan darah tinggi, tenggorokan kering, ketegangan otot, denyut jantung cepat, telapak tangan berkeringat, dan ketegangan otot di perut Anda (Parnabas, Mahamood, \& Parnabas, 2013).(2) Worry, didefinisikan sebagai gagalnya usaha pemecahan masalah dimana bahaya berlangsung tanpa solusi yang pernah ditemukan (Mathews, dalam Khawaja, \& Chapman, 2007). Worry dapat dimulai dengan pikiran-pikiran otomatis yang negatif. Proses berpikir ini dimulai dengan secara selektif fokus pada isyarat mengancam dan menafsirkan mereka dalam sebuah cara yang tidak realistis dan mengancam. Worry diindikasikan dengan kekhawatiran tentang berkinerja buruk dan konsekuensi negatif yang dihasilkan (Smith, Smoll, Cumming, \& Grossbard, 2006). Khawatir dibuktikan berkaitan dengan kepercayaan pemecahan masalah yang buruk, proses kognitif yang melibatkan kecenderungan untuk meragukan dan menurunkan rasa kemahiran seseorang, keberhasilan dan kemampuan untuk memecahkan masalah (Davey, dalam Khawaja \& Chaoman, 2007).(3) Concentration disruption, Concentration disruption mengindikasikan kesulitan dalam berfokus pada isyarat tugas yang terkait (Smith, Smoll, Cumming, \& Grossbard, 2006). Concentration disruption sangat erat hubungannya 
dengan aspek sosial, hal ini disebabkan karena Concentration disruption dapat diprediksi oleh tindakan dan pikiran yang melibatkan lingkungan sekitar kita.

\subsection{Kepercayaan Diri}

Self confidance (percaya diri) merupakan aspek kepribadian yang mutlak harus dimiliki olah seorang yang ikut dalam bertanding karena berkaitan dengan keyakinan "saya bisa". Meskipun sering mendengar penari dan pelatih berbicara tentang percaya diri diatas panggung . itu bukan istilah yang mudah untuk dapat dipraktekkan. Menurut Lauster (2012) Self-confidence (kepercayaan diri) merupakan suatu sikap atau perasaan yakin atas kemampuan yang dimiliki sehingga individu yang bersangkutan tidak terlalu cemas dalam setiap tindakan, dapat bebas malakukan hal-hal yang disukai dan bertanggung jawab atas segala perbuatan yang dilakukan, hangat dan sopan dalam berinteraksi dengan orang lain. Menurut Horn (2008) self confidance sebagai keyakinan bahwa seseorang memiliki sumber daya internal, terutama kemampuan, untuk mencapai keberhasilan .Menurut Miskell (dalam Rahayu, 2013) kepercayaan diri adalah penilaian yang relatif tentang diri sendiri, mengenai kemampuan bakat, kepemimpinan dan inisiatif, serta sifat-sifat lain dan kondisi yang mewarnai perasaan manusia .Menurut Liendenfield (2007) mendefinisikan kepercayaan diri adalah kepuasan seseorang akan diri sendiri. Kepercayaan diri menurut Muhid (2013) dimana terdapat ciri - ciri seorang yang percaya diri yaitu merasa berani menghadapi tantangan yang dilakukan baik yang disukainya, seorang akan lebih bertanggung jawab secara pribadi pada kinerjanya serta cenderung mengerjakan tugas dengan tingkat kesulitan sedang maupun tinggi dan memiliki dorongan untuk selalu aktif mendekati tujuannya, dengan begitu mereka dapat merasa bahagia disaat mampu menyelesaikan suatu tugas dengan berhasil.

Kumara (dalam Ghufron, 2014) menyatakan kepercayaan diri merupakan ciri kepribadian yang mengandung arti keyakinan terhadap kemampuan diri sendiri. Hal ini senada dengan pendapat Afiatin dan Andayani (dalam Ghufron 2014) yang menyatakan kepercayaan diri merupakan aspek kepribadian yang berisikan keyakinan tentang kekuatan, kemampuan, dan keterampilanyang dimilikinya. Selain itu, Ghufron (2014) juga menyatakan kepercayaan diri adalah keyakinan untuk melakukan sesuatu pada diri subjek sebagai karakteristik pribadi yang didalamnya terdapat keyakinan akan kemampuan diri, optimis, objektif, bertanggung jawab, rasional, dan realistis.

Menurut Alfred Adler (dalam Peter Lauster, 2005) yang menyatakan bahwa percaya diri merupakan kebutuhan manusia yang paling penting selain rasa superlioritas.Jadi dapat ditarik butir-butir penting bahwa percaya diri adalah percaya dan yakin akankemampuan serta dapatmengandalkan diri sendiri. Menurut Hakim (2002) kepercayaan diri merupakan suatu keyakinan seseorang terhadap segala sesuatu yang menjadi aspek kelebihan yang dimiliki dan keyakinan tersebut membuatnya merasa mampu untuk mencapai berbagai tujuan hidup dan dapat menyesuaikan diri dengan lingkungannya.

\subsection{Aspek - Asepek Kepercayaan Diri}

Menurut Lauster (dalam Ghufron 2012), ada beberapa aspek dari kepercayaan diri yakni sebagai berikut :(a)Keyakinan akan kemampuan diri yaitu sikap positif seseorang tentang dirinya bahwa dia mengerti sungguh-sungguh akan apa yang dilakukannya. (b) Optimis, yaitu sikap positif seseorang yang selalu berpandangan baik dalam menghadapi segala hal tentang diri, harapan dan kemampuan. (c) Obyektif yaitu orang yang percaya diri memandang permasalahan atau segala sesuatu sesuai dengan kebenaran semestinya, bukan menurut kebenaran pribadi.(d)Bertanggung jawab yaitu kesediaan seseorang untuk menanggung segala sesuatu yang telah menjadi konsekuensinya. (e)Rasional, yaitu analisa terhadap suatu masalah, suatu hal, sesuatu kejadian dengan menggunakan pemikiran yang diterima oleh akal dan sesuai dengan kenyataan.

\section{Metode Penelitian}

Jenis penelitian ini adalah kuantitatif korelasional dengan variabel penelitian Menurut Sugiyono (2014) variabel Dependen, penelitian Kecemasan Bertanding (Y) dan Variabel Independen, Kepercayaan Diri (X). Populasi pada penelitian ini adalah anggota komunitas tari modern di Kota Padang yang berjumlah 150 orang. Teknik pengambilan sampel dalam penelitian ini adalah nonprobability sampling dengan menggunakan metode purposive sampling yaitu teknik pengambilan 
sampel dengan pertimbangan tertentu. Sampel dalam penelitian ini memiliki kriteria yaitu anggota komunitas tari modern di Kota Padang yang aktif dalam berkompetisi, usia 14 tahun keatas, pria dan wanita, mampu berkomunikasi dengan baik, bersedia menjadi responden, pelajar, mahasiswa dan sudah bekerja.. Berdasarkan kriteria diatas, maka sampel penelitian ini berjumlah 105 orang anggota komunitas tari modern di Kota Padang.

Metode pengumpulan data yang digunakan dalam penelitian ini adalah skala model likert untuk mendapatkan data kuantitatif. Skala ini digunakan untuk mengukur sikap, pendapat, dan persepsi seseorang atau sekelompok orang tentang fenomena sosial (Sugiyono, 2015). Skala yang digunakan pada kecemasan bertanding dan Skala kepercayaan diri adalah model likert. Format skala yang digunakan merupakan format yang telah dimodifikasi menjadi empat alternatif jawaban yaitu SS (Sangat Setuju), S( Setuju), TS (Tidak Setuju), dan STS (Sangat Tidak Setuju). Aitem-aitem dalam skala ini dikelompokkan dalam item favourable dan unfavourable. Skala penelitian akan melewati berbagai tahap analisis yaitu uji normalitas digunakan untuk mengetahui apakah populasi data terdistribusi normal atau tidak. Uji normalitas menggunakan uji kolmogorov-Smirnov. Uji linearitas bertujuan untuk mengetahui apakah dua variabel mempunyai hubungan yang linear atau tidak. Dua variabel dikatakan mempunyai hubungan yang linear bila signifikasi (linearty) kurang dari 0,05.

Selain itu dilakukan uji Validitas, sejauh mana ketepatan dan kecermatan suatu alat ukur dalam melakukan fungsi ukurnya (Azwar, 2017). Suatu item dapat dianggap memiliki daya diskriminasi yang memuaskan jika berkorelasi signifikan terhadap skor total atau jika melakukan penilaian langsung terhadap koefisien korelasi bisa digunakan batas nilai berkriteria rxy $\geq 0,3$ (Azwar, 2017). Data skala dikatakan memiliki daya beda tinggi jika koefisien korelasi lebih besar atau sama dengan 0,3 (rxy $\geq 0,3$ ) dan sebaliknya aitem skala dikatakan gugur jika koefisien korelasi lebih kecil dari 0,3 $(\mathrm{rxy} \geq 0,3)$.

\section{Hasil dan Pembahasan}

Peneliti menyebarkan 105 skala Kecemasan Bertanding dan skala Kepercayaan Diri dan meminta kesediaan kepada anggota komunitas tari di Kota Padang tersebut untuk mengisi skala kemudian menjelaskan cara pengisian skala dengan cara memberikan skala secara langsung kepada anggota komunitas tari modern di Kota Padang. Sebelum pengisian skala dilakukan, peneliti terlebih dahulu memberitahukan petunjuk pengisian dengan singkat dan jelas.

\subsection{Hasil}

Koefisien Validitas skala Kecemasan Bertanding dengan nilai corrected item-total correlation berkisar antara 0,324 sampai dengan 0,737, dengan reabilitas 0,919, validitas skala Kepercayaan Diri dengan nilai corrected item-total correlation berkisar antara 0,341 sampai dengan 0,889, dengan reabilitas 0.943. Uji normalitas dalam penelitian ini menggunakan uji Kolmogorov-Smirnov. Priyatno (2018) menyatakan bahwa data yang dinyatakan berdistribusi normal jika signifikansi (p) lebih besar dari 0,05. Berdasarkan hasil pengolahan data dengan menggunakan program IBM SPSS 21.0, Maka diperoleh hasil sebagai berikut:

Tabel 1. Uji Normalitas Skala Kepercayaan Diri dengan Kecemasan Bertanding

\begin{tabular}{ccccc}
\hline Variabel & N & KSZ & P & Sebaran \\
\hline Kecemasan Bertanding & 105 & .994 & .277 & normal \\
Kepercayaan Diri & 105 & .619 & .838 & normal \\
\hline
\end{tabular}

Berdasarkan uraian tabel di atas, maka diperoleh nilai signifikan pada skala Kecemasan Bertanding diperoleh dengan nilai signifikan sebesar $\mathrm{p}=0,277$ dengan $\mathrm{KSZ}=0,994$ hasil tersebut menunjukan bahwa nilai $\mathrm{p}>0,05$ artinya sebaran berdistribusi secara normal, sedangkan skala Kepercayaan Diri sebesar $\mathrm{p}=0,838$ dengan $\mathrm{KSZ}=0,619$. Hasil tersebut menunjukan bahwa nilai $\mathrm{p}>0,05$ artinya sebaran berdistribusi secara normal. Selanjutnya uji linearitas dapat dilihat pada tabel 2 berikut: 
Tabel 2. Uji Linieritas Kepercayaan Diri dengan Kecemasan Bertanding

\begin{tabular}{ccccc}
\hline $\mathbf{N}$ & $\mathbf{D f}$ & Mean Square & F & Sig \\
\hline $\mathbf{1 0 5}$ & 1 & 2387.057 & 52.202 & .000 \\
\hline
\end{tabular}

Berdasarkan uraian tabel di atas, maka diperoleh nilai signifikansi sebesar $p=0,000(p<0,05)$, dapat disimpulkan bahwa antara variabel Kepercayaan Diri dan Kecemasan Bertanding terdapat hubungan yang linier.

Tabel 3. Hasil Uji Korelasi Antara Kepercayaan Diri dengan Kecemasan Bertanding

\begin{tabular}{ccccc}
\hline $\mathbf{P}$ & $(\boldsymbol{\alpha})$ & Nilai Korelasi $(\mathbf{r})$ & R square & Kesimpulan \\
\hline $\mathbf{0 , 0 0 0}$ & 0.01 & $-0,571$ & 0,327 & $\begin{array}{c}\text { sig (2-tailed) } 0,000<0,01 \text { level } \\
\text { of significant }(\alpha), \text { berarti } \\
\text { hipotesis diterima. }\end{array}$ \\
\hline
\end{tabular}

Berdasarkan uraian tabel di atas, maka diperoleh koefisien korelasi antara variabel Kepercayaan Diri dan Kecemasan Bertanding sebesar $r=-0,571$ dengan taraf signifikansi $\mathrm{p}=0,000$, maka dapat disimpulkan bahwa ada hubungan antara Kepercayaan Diri dengan Kecemasan Bertanding pada anggota komunitas tari modern di Kota Padang dengan arah hubungan negatif. Hal ini menunjukkan semakin tinggi Kepercayaan Diri maka semakin rendah Kecemasan Bertanding dan begitu juga sebaliknya, semakin rendah Kepercayaan Diri maka semakin tinggi Kecemasan Bertanding. Hal ini diperkuat dengan hasil uji signifikasi dengan bantuan IBM SPSS versi 21.0 didapatkan $\mathrm{p}=0,000<$ 0,01 level o significant $(\alpha)$, artinya terdapat hubungan yang sangat kuat antara Kepercayaan Diri dengan Kecemasan Bertanding anggota komunitas tari modern di Kota Padang.

Tabel 4. Descriptive Statistic

\begin{tabular}{cccccc}
\hline Variable & N & Mean & Std. Deviation & Minimum & Maximum \\
\hline Kepercayaan Diri & 105 & 85.85 & 10.662 & 64 & 109 \\
Kecemasan & 105 & 84.28 & 8.383 & 65 & 106 \\
Bertanding & & & & & \\
\hline
\end{tabular}

Berdasarkan nilai mean empirik tersebut, maka dapat dilakukan pengelompokkan yang mengacu pada kriteria pengkategorisasian dengan tujuan menempatkan individu kedalam kelompok-kelompok yang terpisah secara berjenjang menurut suatu kontinum berdasarkan atribut yang diukur (Azwar, 2017) sebagai berikut:

Tabel 5. Kategori Kepercayaan Diri dengan Kecemasan Bertanding

\begin{tabular}{ccccc}
\hline Variabel & Skor & Jumlah & Persentase (\%) & Kategori \\
\hline Kepercayaan diri & $64-75$ & 16 & $15,23 \%$ & Rendah \\
& $76-96$ & 72 & $68,57 \%$ & Sedang \\
& $97-109$ & 17 & $16,19 \%$ & Tinggi \\
Kecemasan & $65-76$ & 17 & $16,19 \%$ & Rendah \\
bertanding & $77-93$ & 76 & $72,38 \%$ & Sedang \\
& $94-106$ & 12 & $11,42 \%$ & Tinggi \\
\hline
\end{tabular}

Berdasarkan tabel di atas untuk variabel Kepercayaan Diri diperoleh gambaran sebesar 15,23\% atau 16 orang dikategorikan Kepercayaan Diri yang rendah, sebesar 68,57\% atau 72 orang dikategorikan memiliki Kepercayaan Diri yang sedang dan sebesar 16,19\% atau 17 orang dikategorikan memiliki Kepercayaan Diri yang tinggi. Sedangkan untuk variabel perilaku Kecemasan Bertanding diperoleh gambaran sebesar 16,19\% atau 17 orang dikategorikan memiliki perilaku Kecemasan Bertanding yang rendah, sebesar 72,38\% atau 76 orang dikategorikan memiliki Kecemasan Bertanding yang sedang dan sebesar 11,42\% atau 12 orang dikategorikan memiliki Kecemasan Bertanding yang tinggi.

\subsection{Pembahasan}


Penelitian ini bertujuan untuk mengetahui hubungan antara kepercayaan diri dengan dengan Kecemasan Bertanding pada anggota komunitas tari modern. Berdasarkan uji hipotesis yang dilakukan menunjukkan bahwa terdapat hubungan yang signifikan antara kepercayaan diri dengan kecemasan bertanding pada anggota komunitas tari modern yang ditunjukkan oleh angka koefisien korelasi rxy $=-$ 0,571 dengan tingkat signifikansi korelasi $\mathrm{p}=0,000$. Nilai $\mathrm{r}$ yang diperoleh menunjukkan korelasi yang sedang. Hasil ini mencerminkan adanya korelasi yang sedang antara kepercayaan diri dengan kecemasan bertanding. Nilai yang negative pada koefisien korelasi menunjukkan hubungan negatif antara Kepercayaan Diri dengan Kecemasan Bertanding pada anggota komunitas tari modern, artinya bahwa semakin tinggi Kepercayaan Diri maka semakin rendah Kecemasan Bertanding dan sebaliknya semakin rendah Kepercayaan Diri maka semakin tinggi Kecemasan Bertanding. Hal ini menyatakan bahwa hipotesis diterima.

Hasil penelitian ini sesuai dengan penelitian yang dilakukan oleh Jessi Triana dkk (2019) dengan judul "Hubungan Antara Kepercayaan Diri Dengan Kecemasan Bertanding Atlet Pencak Silat Dalam Menghadapi Salatiga Cup 2018" yang mengatakan Berdasarkan dari hasil analisis data diperoleh hasil koefesien korelasi (rxy) sebesar $-0,732$ dan $p=0,000(<0,01)$. Artinya, bila skor variabel kepercayaan diri meningkat maka skor variabel kecemasan bertanding akan menurun, namun sebalinya apabila skor kepercayaan diri menurun, maka skor kecemasan bertanding akan meningkat. Yang dapat disimpulkan bahwa ada hubungan negatif yang signifikan antara kepercayaan diri dengan kecemasan bertanding atlet pencak silat dalam menghadapi Salatiga Cup 2018.

Hasil uji hipotesis terhadap 105 sampel anggota komunitas Tari Modern DiKota Padang, menunjukkan dari variabel kepercayaan diri diperoleh gambaran sebesar 15,23\% atau 16 orang dikategorikan kepercayaan diri yang rendah, sebesar $68,57 \%$ atau 72 orang dikategorikan memiliki kepercayaan diri yang sedang dan sebesar $16,19 \%$ atau 17 orang dikategorikan memiliki kepercayaan diri yang tinggi. Sedangkan untuk variabel perilaku Kecemasan Bertanding diperoleh gambaran sebesar 16,19\% atau 17 orang dikategorikan memiliki perilaku Kecemasan Bertanding yang rendah, sebesar 72,32\% atau 76 orang dikategorikan memiliki Kecemasan Bertanding yang sedang dan sebesar 11,42\% atau 12 orang dikategorikan memiliki Kecemasan Bertanding yang tinggi.

Dari penelitian yang sudah peneliti lakukan ditemukan bahwa beberapa anggota komunitas tari modern memiliki kecemasan bertanding yang tinggi. Ini dapat dilihat dari hasil uji hipotesis yang menunjukkan sebanyak $11,42 \%$ atau 12 orang berada pada kategori tinggi. Hal ini dikarenakan tingkat kepercayaan diri yang kurang akan Kemampuan diri sendiri. Menurut Fitri Yulianto, H. Fuad Nashori (2006) bahwa kurang percaya diri akan kemampuannya pada saat bertanding, akan membuat atlet akan mengalami ketegangan sebelum bertanding. Ketegangan merupakan bagian dari gangguan kecemasan. Penelitian yang dilakukan oleh Woodman dan Hardy (2003) dalam sebuah meta analisis telah mengungkapkan bahwa adanya hubungan antara kepercayaan diri dengan kecemasan bertanding. Hasil penelitian ini juga mendukung pernyataan Viderman (2007), menunjukkan bahwa kepercayaan diri memegang peranan penting dalam menurunkan kecemasan yang dialami oleh setiap partisipan. Dari hasil analisis data, bahwa kepercayaan diri dan kecemasan mempunyai korelasi pada partisipan. Apabila kecemasan partisipan tinggi, maka kepercayaan diri partisipan rendah.

Sumbangan Efektif Kepercayaan Diri terhadap Kecemasan Bertanding adalah sebesar 33\% dan 67\% lagi faktor lain yang mempengaruhi Kecemasan Bertanding seperti kepribadian, kesiapan fisik dan mental seseorang serta lingkungan dan situasi pertandingan.

\section{Kesimpulan}

Berdasarkan hasil penelitian dan pembahasan, maka dapat ditarik beberapa kesimpulan sebagai berikut : Berdasarkan analisis uji korelasi menunjukkan bahwa terdapat hubungan antara Kepercayaan Diri dengan Kecemasan Bertanding pada anggota komunitas tari modern di Kota Padang dengan arah positif yang artinya semakin tinggi Kepercayaan Diri maka semakin rendah Kecemasan Bertanding dan sebaliknya semakin rendah Kepercayaan Diri maka semakin tinggi Kecemasan Bertanding, hal ini berarti hipotesis diterima. Sumbangan efektif variabel Kepercayaan Diri terhadap Kecemasan Bertanding ini sebesar 33\%.

\section{Daftar Rujukan}


[1] Agung, A.A.P dkk (2018). Hubungan Kecerdasan Emosional Dengan Kecemasan Bertanding Pada Atlet Softball Remaja Putri Di Bali. Jurnal 2018, Vol.5,No.1,218-225 . Universitas Udayana

[2] Azwar, Saifuddin. (2014). Metode Penelitian Psikologi. Yogyakarta :Pustaka Pelajar

[3] Azwar, Saifuddin. (2017). Metode Penelitian Psikologi. Yogyakarta :Pustaka Pelajar

[4] Azwar, Saifuddin. (2016). Penyusunan Skala Psikologi. Yogyakarta :Pustaka Pelajar

[5] Dian, I.P dkk. (2016). Kepercayaan Diri dan Kemandirian Belajar Pada Siswa SMA Negeri "X". Jurnal Psikologi Teori \&Terapan, Vol.7, No.1,Agustus 2016 : Universitas Negeri Surabaya

[6] Ghufron, Nur dkk (2012). Teori - Teori Psikologi. Yogyakarta : AR-RUZZ MEDIA

[7] Luiselli K.J dkk. (2011). Behavioral Sport Psychology. London : Business Media.

[8] Mutiara, R.I ( 2018). Hubungan Antara Kepercayaan Diri Dengan PenyesuaianSosial Pada Peserta Didik Kelas Vii Di Smp Negeri 3 bandar Lampung.Skripsi : Universitas Islam Negeri Raden Intan Lampung.

[9] Pangestianto, B. (2018). Hubungan Kepercayaan Diri Dengan Adversity Quotient Karyawan (Pada Frontliner Bri Tulung Agung). Skripsi : Universitas Muhammadiyah Malang.

[10]Prayitno, Duwi. (2018). SPSS Panduan Mudah Olah Data Bagi Mahasiswa \& Umum. Andi: Yogyakarta.

[11]Putri, Y. I. (2007). Hubungan Antara Intimasi Pelatih-Atlet Dengan KecemasanBertanding Pada Atlet Ikatan Pencak Silat Indonesia (IPSI) Semarang. Skripsi: Universitas Diponegoro.

[12] Sugiyono.(2014) Metode Penelitian Kuantitatif dan Kualitatif. Alfabeta.Bandung.

[13] Syam, A dkk (2017). Pengaruh Kepercayaan Diri (Self Confidence) Berbasis Kaderisasi Imm Terhadap Prestasi Belajar Mahasiswa (Studi Kasus Di Program Studi Pendidikan Biologi Fakultas Keguruan Dan Ilmu Pendidikan Universitas Muhamadiyah Parepare). Jurnal Biotek Volume 5 Nomor 1 Juni 2017 : Univerrsitas Muhammadiyah Parepare.

[14] Syahputra, A (2018) .Hubungan Seklf Disclosure dengan Kecemasan Bertanding pada Atlet Sepakbola Di Pekanbaru Riau. Skripsi : Universitas Islam Negeri Sultan Kasim Riau.

[15] Triana, J dkk. (2019). Hubungan Antara Kepercayaan Diri Dengan Kecemasan Bertanding Atlet Pencak Silat Dalam Menghadapi Salatiga Cup 2018. Jurnal Vol. 15 No. 2, Desember 2019. Jurnal : Universitas Kristen Satya Wacana Salatiga.

[16] Unzilla, A.D dkk (2016) . Konsep Kepercayaan Diri Remaja Putri. Jurnal Pendidikan Indonesia Volume 2 Nomor 2, 2016, Hlm 43-52 : Universitas Negeri Padang.

[17] Wahyu, P.A dkk. (2018). Mental Toughness dan Competitive Anxiety pada Atlet BolaVoli. Jurnal pISSN: 2301-8267 | eISSN: 2540-8291Vol. 06, No.01 Januari 2018 : Universitas Muhammadiyah Malang. 